\title{
Democracy and elections in Africa in the Democratic Republic of Congo: Lessons for Africa
}

\author{
ANDRE MBATA B MANGU \\ Professor in the Department of Constitutional, International and Indigenous \\ Law, University of South Africa
}

MPRARISENI BUDELI

Senior Lecturer, Department of Mercantile Law, University of South Africa

\section{INTRODUCTION}

While regular multi-party elections do not necessarily guarantee the establishment of a democratic state, no state can be said to be democratic if it does not hold regular elections according to a set of rules that are fair to the political parties involved. In Africa, many countries moved away from one party states towards a system of multipartyism in the late nineteen eighties ,but this has not always resulted in the establishment of true democracy. In this article we discuss the requirements for democracy and for free and fair elections against the background of the recent experience of the Democratic Republic of Congo ('DRC') which - with assistance from various international role players - has moved from a deeply authoritarian system to a multi-party system of government. We evaluate this experience and ask whether true democracy has now been established in the DRC and what this process can tell us about experiences elsewhere in Africa.

\section{HISTORICAL BACKGROUND}

Since its independence from Belgium on 30 June 1960, the history of the $\mathrm{DRC}^{1}$ has been a succession of coups d'état, secession attempts, aggression by foreign troops, civil wars, rebellions, lootings, authoritarian regimes, United Nations (UN) interventions, and national conferences or dialogues. ${ }^{2}$

On 24 November 1965, General Mobutu Sese Seko seized power in a coup d'état and later established the Mouvement Populaire de la Révolution (MPR) as a single party in the country. In May 1997, his regime was toppled by the rebels of the Alliance des Forces Démocratiques de Libération (AFDL) led by Laurent Désiré Kabila. An armed conflict broke out in 1996 and lasted for two

Hereinafter the DRC.

2 Mkandawire T Introduction in Mbaya Kankwenda (ed) Le Zaïre vers quelles destinées? (1992) IX-X. 
years. This conflict can be viewed as more than an internal rebellion because it was also fanned by foreign aggression financed by Mobutu's erstwhile Western allies and supported by his foes in the central and Southern African regions, notably the leaders of Rwanda, Uganda, Angola, Burundi, Namibia, Zimbabwe and even South Africa. ${ }^{3}$ In August 1998, Rwanda and Uganda supported a new rebellion and invaded the DRC, as Laurent-Désiré Kabila no longer served their interests. This time around, the Kinshasa regime could count on Angola, Namibia and Zimbabwe for support. The DRC was once more at war. It became the battle ground for many national armed forces and foreign armies siding with either Kabila or with his opponents in the rebellion. In the words of Howard Wolpe, the then US Special Envoy to Africa's Great Lakes region, the DRC war was "the most widespread interstate war in modern African history," ${ }^{4}$ considered by some analysts "the African equivalent of World War I" and labelled "the African war". ${ }^{5}$ The UN intervened once again by establishing the UN Mission in the Congo (MONUC). This intervention was reminiscent of the UN intervention of the 1960s when a UN Force was deployed in the Congo (ONUC) to end the first Congolese crisis. ${ }^{6}$

Some forty years on, the country has gone from one DRC to another $\mathrm{DRC}^{7}$ and from a crisis of the Congo in the 1960s to another crisis of the Congo in the 1996-1997, with actors nearly identical to the ghosts of the past. ${ }^{8}$ The political and constitutional history of the Congo has been repeating itself in a vicious circle of coups and counter-coups, rebellions, mutinies, roundtables and unconstitutional regimes, all unfolding simultaneously as both tragedy and farce. ${ }^{9}$

To bring the recent DRC crisis to an end, international efforts within the UN, the Organisation of African Unity (OAU)/African Union (AU), and the European Union (EU) and key powers such as Canada, Belgium, the former colonial power, Britain, France, the USA, encouraged the Inter-Congolese Dialogue (ICD) that was hosted by South Africa in Sun City between 2002

3 Mangu A "Conflict in the Democratic Republic of Congo: An international legal perspective" (2003) 28 South African Yearbook of International Law 93-98; Mangu A "The Conflict in the Democratic Republic of Congo and the protection of rights under the African Charter" African Human Rights Law Journal (2003) 235, 238-245.

4 Wolpe H "The Great Lakes crisis: an American view" (2000) 7 South African Journal of International Affairs 27.

5 Mangu (fn 3 above) 237; Mangu "From war to peace: the Democratic Republic of Congo in transition" South African Journal of International Affairs (2003) 10159 - 160.

6 Mangu (fn 3 above) at 160-163.

7 In 1972, President Mobutu changed the name of the country from DRC as it was known at independence to Zaire in line with his policy of authenticity that outlawed foreign names and denominations and rather favoured African, traditional and pre-colonial names. When he came to power in May 1997, President Laurent-Désiré Kabila renamed the country that recovered its previous name as 'DRC.'

8 Mkandawire (fn 2 above) IX-X.

9 Ibid. 
and 2003. ${ }^{10}$ In 2002, Congolese leaders from the government, the different rebel groups and civil society adopted a global and inclusive agreement that was finally signed in Pretoria on 17 December 2002. ${ }^{11}$ This agreement was later adopted by the ICD and based on it the ICD adopted an Interim Constitution on 2 April 2003. The Interim Constitution came into force on 4 April 2003 after President Joseph Kabila assented to it. ${ }^{12}$ In May 2005, Parliament adopted the final Constitution. This Constitution was approved by popular referendum held on 18 and 19 December 2005. It entered into force on 18 February 2006. ${ }^{13}$ Shortly after the promulgation of the 2006 Constitution, the DRC Parliament adopted the Electoral Act, which the President assented to on 9 March 2006. ${ }^{14}$ The Electoral Act was to be enforced by the Electoral Independent Commission (EIC). ${ }^{15}$ This Act and the relevant provisions of the Constitution constituted the electoral laws and governed the elections that where held in 2006 in order to establish or rather consolidate democracy in the DRC.

Against this background, this article reflects on democracy and elections in Africa. It will first examine the electoral laws and systems in the DRC. It will then discuss the 2006 DRC elections. Municipal and local elections are still forthcoming and are therefore beyond the scope of this article. Apart from the DRC case, the article will engage with the concepts of democracy, multipartism and elections, which are the key concepts of the study, and draw out lessons on democratic consolidation for the African continent as a whole. It will end with a brief conclusion.

\section{ELECTORAL LAWS AND SYSTEMS IN THE DRC}

The rules that governed the electoral process in the DRC were to be found in the Constitution, in the Electoral Act and in a number of decisions and guidelines set up by the EIC. ${ }^{16}$ It is worth examining these laws and the electoral

10 Mangu (fn 3 above)160-168. The ICD opened in Addis-Ababa in October 2001 but could not finish its work due to financial problems and disputes over parties' representation. It then moved to Sun City, South Africa, where it reopened on 25 February 2002. It was adjourned on 19 April 2002, as the participants could not reach an inclusive agreement after 52 days of negotiation. Several initiatives of mediation among the Congolese parties resulted in the resumption of the dialogue in Sun City on 1 April 2003. They finally agreed on a draft constitution to govern country during a transitional period of 24 to 26 months. The draft Constitution, which was signed into law on 4 April 2003, was based on the Global Agreement signed by the parties in Pretoria, RSA, on 17 December 2002 and provided for a government of national unity during the transition. The latter was to end with the organisation of free and fair elections.

11 Mangu (fn 3 above) 166.

12 Mangu (fn 3 above) 168

13 Constitution de la République Démocratique du Congo, 18 février 2006. On the recent constitutional history of the Democratic Republic of Congo, Mangu "Congo, Democratic Republic of the" in Gerhard Robbers (ed) Encyclopedia of World Constitutions Vol 1 (2007) 213-214.

14 Electoral Act no 06/006 of 9 March 2006 relating to the organisation of presidential, legislative, provincial, urban, municipal and local elections. Hereinafter the 'Electoral Act.'

15 Decision No 003/CEI/BUR/06 of 9 March 2006 relating to the implementation of the Electoral Act.

16 See Constitution de la République Démocratique du Congo, numéro spécial, Journal Officiel de la RDC, 47ème année, Kinshasa, 18 février 2006; Electoral Act of 9 March 2006; Decision No 003/CEI/BUR/06 of 9 March 2006. 
systems provided for the presidential, legislative, and provincial elections prior to dealing with the elections.

\subsection{Electoral laws}

The 2006 Constitution states that national sovereignty is vested in the people. ${ }^{17}$ All power emanates from the people who exercise it directly by referendum or elections and indirectly by their representatives. An Act of Parliament sets up the conditions for the organisation of the referendum and the elections. ${ }^{18}$ Suffrage is universal, equal and by secret ballot. With the exceptions established by the Constitution, all Congolese citizens - male or female and older than 18 years of age - enjoy their civil and political rights and are entitled to vote or to be elected to the various democratic bodies. ${ }^{19}$ Political pluralism is recognised. ${ }^{20}$ Any Congolese citizen enjoying civil and political rights is entitled to create a political party or to join a party of his or her choice. Parties are formed and operate freely subject to the law, public order and good morale. ${ }^{21}$ Such parties may receive public funds to finance their activities or electoral campaigns. ${ }^{22}$ The establishment of a one-party system in any form or in any part of the national territory is prohibited and constitutes an offence of high treason. ${ }^{23}$ Political opposition is recognised and its status is determined by an "organic" ${ }^{24}$ law. ${ }^{25}$

Chapter 1 of the Constitution deals with citizenship, which is a prerequisite for anyone to participate in the elections either as a voter or as a candidate. Citizenship is also a critical issue since one of the reasons why the Congolese people have been subjected to long periods of war is that the Congolese people of Rwandan and Tutsi origin known as 'the Banyamulenge' were denied their legitimate right as citizens of the Congo. The Constitution provides that Congolese citizenship is exclusive and cannot be held concurrently with any other citizenship. ${ }^{26}$ Unlike citizenship by naturalisation, "citizenship by origin" is granted to anyone belonging to any ethnic group which inhabited the DRC at independence on 30 June $1960 .{ }^{27}$ The conditions of recognition, acquisition, loss and recovery of the Congolese citizenship are determined by law. ${ }^{28}$

Chapter II of the Constitution deals with human rights, fundamental freedoms and duties of the citizens and of the State. The Congolese Bill of

17 DRC Constitution (fn 13 above) art 5.

18 DRC Constitution (fn 13 above) art 5.

19 DRC Constitution (fn 13 above) art 5.

20 DRC Constitution (fn 13 above) art 6.

21 DRC Constitution (fn 13 above) art 6.

22 DRC Constitution (fn 13 above) Art 6.

23 DRC Constitution (fn 13 above) Art 7.

24 In the French legal system that inspired the legal system of Belgium, the DRC's former colonial power, and ultimately the Congolese system itself, 'organic' laws are those laws considered as such by the Constitution. They complement the Constitution in some critical matters. In the normative pyramid of the sources of domestic law, organic laws rank lower than the Constitution, which is the supreme law of the Republic, but higher than 'ordinary' laws that refer to ordinary Acts of Parliament.

25 DRC Constitution (fn 13 above) art 8.

26 DRC Constitution (fn 13 above) art 10.

27 DRC Constitution (fn 13 above) art 10.

28 DRC Constitution (fn 13 above) art 10. 
Rights entrenches a number of rights supporting multiparty democracy. Several rights, including the right to equality and the right to human dignity are safeguarded for everyone living in the DRC while political rights are recognised for Congolese citizens only. ${ }^{29}$ Other rights included in the Bill of Rights and extended to "everyone", include the right to individual freedom, ${ }^{30}$ the right to freedom of thought, conscience and religion, ${ }^{31}$ the right to freedom of expression, ${ }^{32}$ the right to information, freedom of press and the media,,$^{33}$ the right to freedom to assemble unarmed, ${ }^{34}$ the right to demonstrate, ${ }^{35}$ the right to petition individually or collectively public authorities, ${ }^{36}$ and the right to freedom of association. ${ }^{37}$ The Constitution also enshrines the right to nondiscrimination, ${ }^{38}$ including non-discrimination against women. One of the biggest innovations of the 2006 DRC Constitution is the entrenchment of the "parity" principle between man and woman. ${ }^{39}$ This principle requires a fair representation of men and women in all political institutions in the national, provincial or local spheres of government. ${ }^{40}$

The Electoral Act passed in terms of the Constitution ${ }^{41}$ provides for the organisation of presidential, legislative, provincial, municipal and local elections. For each election, the Electoral Act determines the constituency, the conditions for eligibility, the time and duration of the campaign, and the electoral operations to be conducted from the time voting commence to the time the final results are promulgated. It also clearly sets out the role of the EIC in this process.

\subsection{Electoral systems}

The legal framework provides for the direct election of the President, the members of the National Assembly and the members of the provincial assemblies by universal suffrage. However, senators, the governors and vice-governors of provinces are elected indirectly by the members of the provincial assemblies and not directly by the people.

Two electoral systems were used during the 2006 DRC elections, namely the majority system and the proportional representation system.

The majority system under territorial or regional representation was adopted for the presidential election and for the election of governors and vice-governors of the provinces..$^{42}$ The DRC territory constituted a single constituency

29 DRC Constitution (fn 13 above) art 1.

30 DRC Constitution (fn 13 above) art 17.

31 DRC Constitution (fn 13 above) art 22.

32 DRC Constitution (fn 13 above) art 23.

33 DRC Constitution (fn 13 above) art 24.

34 DRC Constitution (fn 13 above) art 25.

35 DRC Constitution (fn 13 above) art 26.

36 DRC Constitution (fn 13 above) art 27.

37 DRC Constitution (fn 13 above) art 37.

38 DRC Constitution (fn 13 above) art 13.

39 DRC Constitution (fn 13 above) art 14.

40 DRC Constitution (fn 13 above) art 14.

41 DRC Constitution (fn 13 above) art 5.

42 Electoral Act ( fn 14 above)arts 114, 170, 189, 197, 205, and 221. 
for the president while the provinces formed the constituencies for the election of governors and vice-governors. The candidate who obtained the most votes was declared elected. The governors and vice-governors ${ }^{43}$ were elected for five years by the members of the provincial assemblies and inaugurated by the President ${ }^{44}$ who was himself directly elected by the people for the same period. The President is allowed to serve for two terms only. ${ }^{45}$

The DRC Electoral Act adopted a mixed electoral system for the election of the members of the National Assembly, the Senate, and the Provincial Assemblies. ${ }^{46}$ The national ${ }^{47}$ and provincial deputies ${ }^{48}$ and the senators ${ }^{49}$ were also elected for five years in terms of the Constitution. For the election of the members of the National Assembly and the provincial assemblies, suffrage was uninominal in a constituency entitled to one seat only. The candidate who obtained most votes was elected. Where a constituency was entitled to more than two seats, the system was that of proportional representation with open lists. In this case, the candidates were presented on lists drawn up by their respective parties unless they were independent candidates who compiled their own lists. The voter was entitled to cast one vote for a candidate on a particular list and the vote counted for the entire list. The total number of votes of a list was the total of votes obtained by different candidates on that list. An electoral quotient was obtained by dividing the total number of votes by the number of seats in a constituency. For each list, the total number of votes obtained was equal to the total number of votes obtained by candidates on that list divided by the electoral quotient. The seats were then distributed among the different lists proportionally to the number of votes won by the candidates on those lists. The highest-rest rule applied. The list of the party or the independent candidate that got most votes after division of the total number of votes by the electoral quotient was elected. In case there were still seats available, these seats were reserved for the list(s) with the highest rest(s).

This kind of proportional representation is a very complicated electoral system. Both candidates and voters found it confusing as some calculation is needed to determine the list or the party that won most votes and the particular candidate elected on the list. However, its main advantage is that it allows for a better reflection of the will of the electorate as small parties are also represented in the legislature. The election of the members of Senate also followed the proportional representation system. Unlike national and provincial Deputies, who are members of the National Assembly and the provincial assemblies respectively, the Senators were not directly elected by the people but rather by the members of the provincial assemblies.

\footnotetext{
43 Electoral Act (fn 14 above) art 198 al 2; arts 158-173, 235 of the Electoral Act of 9 March 2006.

44 Electoral Act (fn 14 above) arts $70-73,76$.

45 DRC Constitution (fn 13 above) arts 68-71; Electoral Act (fn 14 above) arts 100-114, 22.

46 Electoral Act (fn 13 above) arts 118-119, 130, 146, 175, 193, 209.

47 DRC Constitution (fn 13 above) arts 101-103; Electoral Act (fn 14 above)arts 115-127, 224-232.

48 DRC Constitution (fn 13 above) art 197; Electoral Act (fn 14 above) arts 143-157, 233-234.

49 DRC Constitution (fn 13 above) arts104-106; Electoral Act (fn 14 above) arts 128-142, 224-232.
} 


\section{DRC ELECTIONS}

The EIC identified 25,712,552 citizens as voters. Two hundred and sixtyseven (267) political parties and independent candidates were registered to compete. Much of the funding of the DRC elections was provided by external and foreign sources. The international community - mainly the UN and the EU - contributed around $\$ 460$ million. ${ }^{50}$ Individual countries such as South Africa, Canada, the USA, Britain, Belgium and France also contributed materially and financially to the organisation of the elections.

This discussion of the DRC elections follows the sequence in which these elections were organised, starting with the election of the members of the National Assembly and the first round of the presidential election on 30 July 2006 to the election of the governors and vice governors and the members of the Senate held during the first semester of 2007, through the second round of the presidential election and the election of the members of the provincial assemblies on 30 October 2006.

\subsection{Presidential elections}

Thirty-three candidates, including four women, registered and campaigned during the DRC 2006 presidential election. Six candidates were independent candidates. President Joseph Kabila was among these independent candidates despite the fact that everyone knew that he was the founder of the Parti du Peuple pour la Reconstruction et le Développement (PPRD) and this party had earlier announced during its congress that President Joseph Kabila would be its presidential candidate. Arguably, President Kabila decided to present himself as an independent candidate in order to win the crucial votes of many of his supporters in other parties and in the civil society. Three of his four vice-presidents during the transition also competed for the presidency. Vicepresidents Azarias Ruberwa, Jean-Pierre Bemba, and Arthur Zaidi Ngoma were presented by the Rassemblement Congolais pour la Démocratie (RCD), the Mouvement de Libération du Congo (MLC), and the Camp de la Patriel Forces du Futur respectively.

The list of presidential candidates included former ministers who had served in the transitional government or in the cabinet of the Mobutu regime. Presidential candidates such as Dr Kashala Lukumuenda, Father Banyingela Kasonga, and Professor Osée Muyima Ndjolo spent many years outside the DRC and their parties were registered only a few months ahead of the elections. The overwhelming majority of the presidential candidates were unable to run a 30-day electoral campaign in a country larger than Western Europe and without adequate transport and communications infrastructures. Those in power, particularly President Kabila and his three vice-presidents, were therefore advantaged because of these logistical difficulties faced by less wellresourced candidates. Ruling the country for almost three years gave them a serious advantage over other candidates. During the campaign, for instance,

50 See http://fr.wikipedia.org/wiki/Election_in_the_Democratic_Republic_of_Congo2006_General_Election accessed on 8 October 2007. 
they were welcomed throughout the Republic in their respective capacities as president and vice-presidents during the transition and treated differently from other presidential candidates.

The provisional results were released by the EIC on 22 August 2006 and these results were later confirmed by the Supreme Court of Justice ${ }^{51}$ acting as the Constitutional Court in the interim period. Joseph Kabila was the frontrunner with $44,81 \%$. He was directly followed by Jean-Pierre Bemba Gombo (20,03\%), Antoine Gizenga (13, 06\%), Francois Joseph Nzanga Mobutu (4,77\%), Oscar Kashala (3,46\%), Azarias Ruberwa (1,69\%), Pierre Pay Pay (1,58\%), and Vincent de Paul Lunda Bululu $(1,40 \%) .{ }^{52}$ Each of the 25 remaining presidential candidates won less than $1 \%$ of votes. Since no candidate won an outright majority on 30 July 2006, a second round of voting took place on 29 October 2006 between the two front-runners, namely Joseph Kabila and Jean-Pierre Bemba. ${ }^{53}$ On 15 November 2006, the EIC proclaimed Joseph Kabila the winner of the election with $58,05 \%$ of the votes against Jean-Pierre Bemba who obtained $41,95 \%$ of the votes cast. Jean-Pierre Bemba appealed to the Supreme Court of Justice alleging massive irregularities and vote-rigging. However, these results were upheld by the Supreme Court of Justice in its judgment delivered on 27 November 2006. ${ }^{54}$ President Kabila was then sworn in and took office on 6 December 2006.

\subsection{Election of members of the National Assembly}

The country was divided into one hundred and sixty-nine constituencies for the election of the members of the National Assembly. Nine thousand six hundred and thirty-two candidates competed for the five hundred seats. ${ }^{55}$ Most of them were presented by the two hundred and sixty-seven parties, but a sizeable number of candidates also took part as independent candidates.

The results released by the EIC in September 2006 and later upheld by the Supreme Court of Justice confirmed the dominance of some political parties or coalitions in national politics. ${ }^{56}$ These include PPRD (Kabila's party), MLC (Bemba's party), PALU (Parti Lumumbiste Unifié, Gizenga's party), MSR (Mouvement Social pour le Renouveau, a party led by presidential advisor Pierre Lumbi), Forces de Renouveau (Party led by Minister Mbusa Nyamuisi),

51 See http://fr.wikipedia.org/wiki/election_presidentielle_congolaise_de_2006 accessed on 8 October 2007.

52 Antoine Gizenga was the leader of the Parti Lumumbiste Unifié (PALU) and a vice-prime minister in the first Congolese cabinet which was formed by Prime Minister Lumumba at independence. François Joseph Mobutu Nzanga is the son of the late dictator Mobutu Sese Seko. Oscar Kashala is a Congolese medical doctor well established in the USA and turned politician. Azarias Ruberwa was one of the four vice-presidents during the transition. Pierre Pay Pay was the governor of the Banque Centrale du Congo (Reserve Bank) for more than two decades under Mobutu while Vincent de Paul Lunda Bululu is a former Prime Minister under Mobutu.

53 See http://fr.wikipedia.org/wiki/election_presidentielle_congolaise_de_2006 (Deuxième tour) accessed on 8 October 2007.

54 Ibid.

55 See http://www.un.org/apps/newsFr/storyFAr.asp?News accessed on 8 October 2007.

56 See http://en.wikipedia.org/wiki/ Democratic_Republic_of_the_Congo_general_election_parliamentary accessed on 8 October 2007. 
and RCD (Ruberwa's party) ex aequo with CODECO (Coalition des Démocrates Congolais), and CDC (Convention des Démocrates Chrétiens) that won 111 seats, 64 seats, 34 seats, 27 seats, 26 seats, 15 seats and 10 seats respectively. The remaining parties won less than ten seats each while independent candidates together won sixty-three seats. However, most of them were financially and materially assisted by the PPRD during the electoral campaign and were therefore Kabila's allies. The Alliance de la Majorité Présidentielle (AMP), a coalition - not a single party - formed by President Kabila's PPRD and allies (mainly Gizenga's PALU and Nzanga Mobutu's UDEMO) in the run-up to the second round of the presidential election against Jean-Pierre Bemba and his Union pour la Nation (UN), constituted the majority that formed the government. The inaugural session of the National Assembly was convened on 22 September 2006 to enable the National Assembly to adopt the rules for its proceedings, validate the mandate of its members and elect its presiding officers. Mr Vital Kamerhe, formerly Secretary-General of the PPRD, was elected Speaker of the National Assembly.

\subsection{Elections of the members of the Provincial Assemblies}

The election of the members of the provincial assemblies (Provincial Deputies) was organised the same day as the second round of the presidential election on 29 October 2006. For this election, the Republic was divided into one hundred and eighty-nine constituencies (24 for Kinshasa and 165 for the provinces) for six hundred and ninety seats. ${ }^{57}$ Six hundred and thirty-two members were elected directly by the people while fifty-eight members were nominated by traditional leaders. ${ }^{58}$

Out of the 632 members of the provincial assemblies to be elected in the eleven provincial assemblies, the PPRD, MLC, RCD and Forces du Renouveau won 133, 102, 42, and 33 seats respectively. ${ }^{59}$ Fifteen political parties won between five and nineteen seats, eighteen between two and four, and thirty-seven won one seat each in the provincial assemblies. The provincial assemblies were inaugurated in January 2007.

As was the case with the National Assembly elections, the PPRD and its allies within the AMP won most seats, followed by the MLC and its allies within the Union for the Nation (UN). The RCD improved on its results during the presidential election and the election of the members of the National Assembly to become the third force in the provincial assemblies.

The PPRD and its allies within the AMP control the majority of the provincial assemblies, including the Provincial Assembly of the capital city of Kinshasa. The opposition of the Union pour la Nation won the majority in the provincial assemblies of four provinces, namely Kasai Occidental, Kinshasa,

57 Electoral Act (fn 14 above) relating to the organisation of presidential, legislative, provincial, urban, municipal and local elections, Annex II.

58 Electoral Act (fn 14 above) art $152-156$. The Electoral Act also relates to the organisation of presidential, legislative, provincial, urban, municipal and local elections, Annex II.

59 See http://www.digitalcongo.net/article/39312 accessed on 8 October 2007. 
Bas-Congo, and Equateur. However, due to electoral practices dominated by corruption and ethnicity, the MLC and the UN succeeded in getting control over one governorship of a province and three Speakers of provincial assemblies. Their candidate was selected as governor in the Equateur province while their candidates were selected as Speakers of the provincial assemblies of Equateur, Kasai Occidental and Bas-Congo respectively.

As far as women's representation is concerned, no woman was elected Speaker. Only three women, namely Emilie Matshoko, Lucie Shungu and Caroline Nziana, were elected Deputy Speakers in the provincial assemblies of the city of Kinshasa and the provinces of Kasai Oriental and Province Orientale respectively. This signals that, despite the 'parity' principle enshrined in the Constitution, parties did little to comply with this principle. On the other hand, women have not played a significant role in ending the discrimination against them in national politics by ensuring that the parity principle was respected by political leaders.

\subsection{Elections of the members of Senate}

The Senators were elected by the Provincial Assemblies on 19 January 2007. The electoral campaign took place between 15 and 17 January 2007. The Senate was inaugurated on 3 February 2007. Like in the Provincial Assemblies, the major parties in the Senate were the PPRD (22 seats), MLC (14), and RCD (7), followed by Forces du Renouveau (7) PDC (6), MSR (3), CDC (3) and PALU (2). ${ }^{60}$ Eighteen other parties won one seat each. However, as is the case in the National Assembly and most provincial assemblies, the PPRD and its allies in the AMP hold the majority in the Senate which comprises one hundred and eight members, including only five women. Nevertheless, $\mathrm{Mr}$ Kengo wa Dondo, an independent Senator close to the opposition, managed to get elected President of the Senate and in this capacity became the second highest personality in Republic. Some politicians who failed to be elected as members of the National Assembly or the provincial assemblies were elected as senators despite the fact that their parties did not hold the majority in the provincial assemblies.

Some criticism was therefore levelled against the electing system of Senators, with some advocating their direct election by the people, as with the members of the national and provincial assemblies, to avoid corruption. The same was said about the election of governors and vice-governors.

\subsection{Election of the Governors and Vice-governors of Provinces}

The results of the election of Governors and Vice-Governors of provinces were announced on Sunday 28 January 2007. The election of the Governors and Vice-Governors in the two provinces of Kasai was postponed to 10 and

60 See http://en.wikipedia.org/wiki/Elections_in_the_Democratic_Republic_of_the_Congo accessed on 8 October 2007. 
then to 15 February 2007 following the disqualification by the EIC of the two candidates presented by the MLC on the grounds that they had dual citizenship in violation of the Constitution. The EIC decision was set aside by the Courts of Appeal in both provinces of Kasai. These judgments were later upheld by the Supreme Court of Justice. As pointed out earlier, the Governors and Vice-Governors of the ten provinces, including the city of Kinshasa, are members of the PPRD or their allies, except for the Province of Equateur. ${ }^{61}$

The organisation of free and fair elections was seen as the most critical moment in the democratisation process in the DRC. It also marked the end of the transition. Many commentators and actors within the international community, including the UN, the EU, the AU and individual countries that supported the process, considered the elections to be a fresh start of democracy in the DRC. This finally gives rise to a number of questions that must be considered, starting from the understanding that the DRC elections of 2006 and 2007 were not the first multiparty elections held in this country. ${ }^{62}$ This serves as a reminder that, even though elections are now well established in many parts of Africa, such multi-party elections unfortunately often fail to bring about democracy in the country concerned.

\section{DEMOCRACY, MULTIPARTYISM AND ELECTIONS WITH REGARD TO THE DRC CASE AND LESSONS FOR THE REST OF AFRICA}

With more and more African countries calling for or opting for elections, it is important to revisit the concept of democracy and its relationship to multipartyism and elections and to use the DRC experience to draw out lessons for the rest of the continent.

\subsection{Revisiting the concept and the relationship between democracy, multipartysim and elections in Africa}

\subsubsection{Democracy}

Democracy is a complex concept that is closely related to multipartyism and elections. As Hoffman pointed out, democracy is the most discussed and contested notion of political theory. ${ }^{63}$ Nwabueze stressed that "no word is more susceptible of a variety of tendentious interpretations than democracy." 64 According to Wiseman, "[m]any governments of quite different types wish

61 See http://en.wikipedia.org/wiki/Elections_in_the_Democratic_Republic_of_the_Congo_gubernatorial_elections accessed on 8 October 2007.

62 The DRC went to multiparty elections shortly before independence in 1960. The legislative elections were won by the Mouvement National Congolais (MNC) led by Patrice-Emery Lumumba who then became Prime Minister in terns of the parliamentary system established by the Congolese Basic Law. General elections, which were preceded by a constitutional referendum, were once more held in 1964. The coalition led by Moïse Tchombe won the majority in Parliament, which allowed him to become Prime Minister.

63 Hoffman J State, Power and Democracy: contentious concepts in practical political theory (1988) Sussex; Wheatsheat Books 31.

64 Nwabueze BO "Constitutionalism in the emergent states" (1973) London: Hurst, Enugu: Nwamife Publishers 1. 
to describe themselves as democratic". ${ }^{65}$ The paradox is that in many cases where states have described themselves as democratic - such as in the German Democratic Republic and the People's Democratic Republic of Yemen - the states concerned appeared significantly undemocratic. ${ }^{66}$

Democracy has acquired different, even contradictory, meanings. It has been used and abused ${ }^{67}$ to such an extent that defining it is a challenge. ${ }^{68}$

Two major conceptions of democracy may lead to confusion about the way in which democracy should be defined or the basis according to which countries should be judged democratic or not. There is, indeed a minimalist and a maximalist conception of democracy. These conceptions of democracy have been informed by the two dominant ideologies of the past century, namely liberalism and socialism. In mainstream scientific discourse these conceptions of democracy are generally set out as being at opposite ends of the spectrum. ${ }^{69}$ In maximalist conceptions, democracy is defined as a regime based on some core values and principles. It is a regime that seeks to protect and promote human rights that are understood broadly to encompass individual, civil and political rights as well as group, social and economic rights. Maximalist conceptions of democracy have been propounded mainly by African and socialist scholars such as Claude Ake, ${ }^{70}$ Issa Shivji, ${ }^{71}$ and Samir Amin. ${ }^{72}$

On the other hand, minimalist conceptions are basically procedural, formal and institutional. Democracy is considered a specific political machinery of institutions, processes and rules. ${ }^{73}$ These include institutions such as elections and representation in elected structures via political parties.

The notion of procedural or institutional democracy is of the sort found in Robert Dahl's concept of polyarchy. ${ }^{74}$ According to Dahl, polyarchy in a political order is characterised by seven institutions, all of which must be present. These are elected officials, free and fair elections, inclusive suffrage,

65 Wiseman JA "Democracy in black Africa. Survival and revival" New York: Paragon House Publishers (1990) 4

66 Wiseman JA (fn 65 above).

67 Sono T "Comments on democracy and its relevance in Africa" (1992) African Perspective: Selection of Works 3; Mangu A "The road to constitutionalism and democracy in post-colonial Africa" LLD Thesis University of South Africa (2002) 173; Wiseman (fn 65 above) 4.

68 Ronen D "The challenges of democracy in Africa" in Ronen D (ed) Democracy and pluralism in Africa Boulder: Lynne Rienner Publishers (1986) 1.

69 Mangu A (fn 67 above) 175.

70 Ake C "Democracy and Development in Africa" (1996) Washington. Dfic: The Brookings Institution 132-134, 137.

71 Shivji IG "Fight My Beloved Continent: New Democracy in Africa" (1992) Harare: SAPES Books 2, 44; Shivju "Contradictory Class Perspectives in the Debate on Democracy" in Shivji I G (ed) State and Constitutionalism: An African Debate on Democracy (1991) Harare: SAPES Books 254-255.

72 Amin S "The Issue of Democracy in Contemporary Third World" in Nyang'oro J E (ed) "Discourses on Democracy: Africa in Comparative Perspective" (1996) Journal of Asian and African Studies 64, 70-71.

73 Ronen D (fn 68 above) at 200.

74 Dahl R "Polyarchy: participation and opposition" (1971) New Haven Yale University Press; Dahl R "Democracy and its critics" (1989) Yale University Press at 220-224; Sorensen G "Democracy and the developmental state" in Nyang'oro (fn 72 above) 72; Mangu A (fn 67 above)176; Wiseman JA(fn 65 above) 8 . 
right to run for office, freedom of expression, alternative information and associational autonomy. ${ }^{75}$ According to Sorensen, Dahl's notion of polyarchy has three elements: competition for governmental power, political participation in the selection of leaders and policies, and civil and political rights. ${ }^{76} \mathrm{In}$ minimalist views, democracy is synonymous with competitive and multiparty democracy. ${ }^{77}$ Support for a minimalist and procedural form of democracy came from liberal scholars such as Glaser, ${ }^{78}$ Huntington, ${ }^{79}$ Hinden, ${ }^{80}$ Sandbrook, ${ }^{81}$ and Wiseman. ${ }^{82}$

As Olukoshi stressed, democracy has an element of process in it: it is a set of institutions and procedures to enable the government of the people by the people and for the people. ${ }^{83}$ Contrary to the view often expressed by proponents of maximalist theories of democracy, individual and civil rights are not simply "bourgeois" concepts. They also matter in a democracy. ${ }^{84}$ However, democracy should not stop at forms and institutions. It must include individual and collective rights, civil and political rights as well as social and economic rights since all human rights are interdependent and interrelated. ${ }^{85}$ Bangura insisted that "although democracy is primarily concerned with the rules and institutions that allow for open competition and participation in government, it embodies also social and economic characteristics that are crucial in determining its capacity to survive" ${ }^{86}$ Modern democracy is also constitutional and multiparty democracy.

As pointed out earlier, the requirements for democracy particularly praised by minimalist and liberal scholars include multipartyism and elections, which are sometimes confused with democracy. ${ }^{87}$

\subsubsection{Democracy and Multipartyism}

Multipartyism presupposes the existence of several parties in a country. A multiparty system is the opposite of 'one-partyism' or even 'no-partyism'. After decades of one-party or no-party systems, several African countries embraced a multiparty system of government in the late 1980s.

75 Ibid.

76 Sorensen (fn 74 above).

77 Mangu A(fn 67 above) 177.

78 Glaser D "Discourses of democracy in the South African left: a critical commentary" in Nyang'oro (fn 72 above) $248-251,270$.

79 Huntington SP "The Third Wave: Democratisation in the Late Twentieth Century" (1991) University of Okalahoma Press 10.

80 Hinden R “Africa and Democracy" (1963) Encounter Pamphlet no. 8 at 9.

81 Sandbrook R "Liberal Democracy in Africa: A Socialist-Revisionist Perspective" in Nyang'oro (fn 72 above) $137-138,143-146$.

82 Wiseman JA (fn 65 above) 6.

83 Olukoshi A "State, conflict, and democracy in Africa: the complex process of renewal" in Joseph $\mathrm{R}$ (ed) State, conflict and democracy in Africa (1999) Boulder \& London: Lynne Rienner Publishers 457.

84 See Glaser (fn 78 above) 248-251; Sandbrook (fn 81 above) 145, Mangu A (fn 67 above) 185.

85 Mangu A (fn 67 above) 185-186.

86 Bangura Y "Authoritarian rule and democracy in Africa: a theoretical discourse," in Nyang'oro (fn 72 above) 98, 107; Mangu A (fn 67 above) 186.

87 Mangu A(fn 67 above) 196. 
According to the liberal theory, there is no democracy without political pluralism, understood as multipartyism. ${ }^{88}$ Political parties have been identified as crucial to the process of democratic transition and consolidation. ${ }^{89}$ However, multipartyism is not democracy. ${ }^{90}$ On the other hand, political parties are relatively recent arrivals on the political scene and, as demonstrated in some pre-colonial African, Asian and European societies, it is possible to have democracy, or some measure of it, without a multiparty system of government. ${ }^{91}$

Where it does exist, multipartyism does not necessarily guarantee democracy because, even in a multiparty system, authoritarianism can overshadow the democratic elements in the system..$^{92}$ Zimbabwe is a recent case in point. Past examples include apartheid South Africa and Mobutu's Zaire. The South African regime under apartheid was an authoritarian one despite the existence of several parties. It was undemocratic as the black people who constitute the overwhelming majority of the population were denied political rights and excluded from the government. In the former Zaire, integral multipartyism with more than four hundred political parties during "Mobutu's guided transition"93 of 1990-1992 did not contribute to the establishment and consolidation of democracy. Instead of advancing democracy, this wild multipartyism rather contributed to the survival of the authoritarian regime of President Mobutu. ${ }^{94}$ Accordingly, mutlipartyism is not synonymous with democracy. Béchir Ben Yahmed rightly warned that those African peoples who would be content with multipartyism, thinking they had already entered the paradise of democracy, would not take long to be disappointed. ${ }^{95}$ Former Zaire, Congo Republic, Burkina Faso, Burundi, Cameroon, Central African Republic, Ethiopia, Gabon and Zimbabwe are but a few African countries where democracy did not prosper despite the establishment of a multiparty system.

Criticism against multipartyism should not, however, be used to celebrate the "one-partyism" or "no-partyism" of a previous era in African politics. ${ }^{96}$ In the 1960s and 1970s, many political leaders and a number of intellectuals backing them justified and praised the one-party state as the best instrument to help build the nation and consolidate national unity, stabilise power and achieve economic development. ${ }^{97}$

88 Mangu A (fn 67 above) 200.

89 Bauer G "Challenges to democratic consolidation in Namibia" in Joseph (ed) (fn 83 above) 439-441.

90 Conac G "Introduction" in Conac G (ed) L'Afrique en transition vers le pluralisme politique (1993) Paris: Economics 5.

91 Mangu A (fn 67 above) 201.

92 Ibid.

93 Mangu A (fn 67 above) 430-434.

94 Ibid.

95 Yahmed BB, as quoted by Pierre-François Gonidec "Démocratie et développement en Afrique: perspectives internationales et nationales" (1993) 14 Afrique 2000 57-58.

96 Mangu A (fn 67 above) 292.

97 Mangu A (fn 67 above) 394. 
Georges Nzongola-Ntalaja wrote that if multipartyism is not necessarily synonymous with democracy, it is difficult, if not impossible, to show that a one-party system, whether of Marxist, socialist, communist or African tradition, can be democratic and contribute to the consolidation of a genuine democracy. ${ }^{98}$ Accordingly, it is worth emphasising once more that although multipartyism is important to ensure the establishment of democracy, it should not be confused with it. Nor should democracy be confused with elections.

\subsubsection{Democracy and Elections}

Elections offer the opportunity for citizens to choose freely between several programmes or policies presented by several parties or candidates. Elections are governed by law, both international (human rights) and domestic law. In international law, the right to vote is a political right entrenched in a number of legal instruments. For example, the Universal Declaration of Human Rights (UDHR) ${ }^{99}$ provides that "everyone has the right to take part in the government of his country, directly or through freely chosen representatives." ${ }^{100}$ This right is supported by the right to freedom of peaceful assembly and association. ${ }^{101}$ Although the UDHR is a UN General Assembly resolution and not binding per se, it can be argued that its acceptance by the overwhelming majority of UN member states has made it binding as part of customary international law. ${ }^{102}$ The International Covenant on Civil and Political Rights (ICCPR), ${ }^{103}$ which is a treaty binding on states parties, also entitles every citizen to take part in the conduct of public affairs of his/her country, directly or through freely chosen representatives, to vote and to be elected at genuine periodic elections which shall be by universal and equal suffrage and held by secret ballot, guaranteeing the free expression of the will of the electors. ${ }^{104}$ The right to vote and to be elected is entrenched in almost all modern Constitutions and electoral laws enacted to enforce them. On the domestic level, there is no single African country where the Constitution does not provide for the right of every citizen to vote during regular, free and fair elections even though electoral politics has taught otherwise. Elections have become a political game, but a game that has to be played according to some agreed rules and principles entrenched in the Constitution and electoral laws. Unfortunately, the rules of the game are very often manipulated by some political leaders to remain in power.

\footnotetext{
98 Nzongola-Ntalaja G "The state and democracy in Africa” in Nzongola-Ntalaja G, Margaret Lee (eds) The state and democracy in Africa (1997) African World Press 15.

99 The UDHR (Universal Declaration of Human Rights 1948 GA res 217 A (III) of 10 December 1948).

100 UDHR (fn above 99) art 21 (1).

101 UDHR (fn above 99) art 20 (1).

102 Dugard J International Law: A South African Perspective 2nd (2000) Juta Publishers 240-242.

103 The ICCPR (International Covenant on Civil and Political Rights 1966 (999 UNTS 171).

104 ICCPR (fn 103 above) art 25 (a) \& (b).
} 
According to Richard Joseph, elections and democracy have become virtually synonymous in Western political thought and analysis. ${ }^{105}$ Claude Ake also observed that more recently, in the hurry to globalise democracy in the aftermath of the ending of the Cold War, democracy was reduced to the crude simplicity of multiparty elections to the benefit of some of the world's most notorious autocrats who were able to parade democratic credentials without reforming their repressive regimes. ${ }^{106}$

In the liberal conception, "elections are the defining institution of democracy". ${ }^{107}$ In his "two-turnover test" according to which consolidation of democracy occurs whenever the winners of founding elections are defeated in a subsequent election, and the new winners accept an electoral turnover, Huntington ${ }^{108}$ also considered elections to be the essence of democracy. According to Olukoshi, the embrace of dubious electoral and political arrangements on the grounds that, at this stage of Africa's development, it is the only outcome that can be realistically expected, is very problematic. ${ }^{109}$ Karl Terry rightly criticised assessments of democracy building and consolidation based on elections or what he labelled "the fallacy of electoralism" ${ }^{110}$ postulating the confusion between democracy and elections.

As we have seen in Latin America and in many African countries, where elections have been organised several times since independence without the country achieving democracy, formal procedures for elections do not create a democracy because elections can and did exist with systematic abuses of human rights and disenfranchisement of large segments of the population. ${ }^{111}$ Georges Nzongola-Ntalaja argues that it would be too simplistic to identify democracy with the holding of elections since the question of democracy goes beyond elections to the realisation of democratic principles of governance and to the balance of social forces in the political community. ${ }^{12}$ Electoral democracies are but cosmetic democracies. ${ }^{113}$ However, while dismissing the "electoral fallacy" or the "fallacy of electoralism", we should not embrace its antithesis, what Mitchell and Booth ${ }^{114}$ called the "anti-electoralist fallacy", which assumes that elections never matter for democratisation. In our modern era, you can have elections without democracy, but you cannot have democracy without elections. ${ }^{115}$

The regularity, openness and acceptability of elections signal whether basic constitutional and attitudinal foundations are being laid for sustainable

\footnotetext{
105 Mangu A (fn 67 above) 196.

106 Ake C (fn 70 above) at 130 .

107 Bratton M, Posner DN “A first look at second elections in Africa with illustrations form Zambia” in Joseph R "State conflict and democracy in Africa” Bouwer London: Lynne Rienne Publishers (1996). 108 Mangu A(fn 67 above) 197.

109 See Olukoshi (fn 83 above) 456; Mangu A (fn 67 above) 197.

110 As quoted by Bratton \& Posner (fn 107 above) at 378.

111 See Bratton \& Posner (fn 107 above) 378-379; Mangu A (fn 67 above) 198.

112 Nzongola-Ntalaja G (fn 98 above) 19.

113 Ake C( fn 70 above)130; Mangu A (fn 67 above) 199.

114 Bratton \& Posner (fn 107 above) 379.

115 Ibid.
} 
democracy. ${ }^{116}$ According to Bratton and Posner, elections remain fundamental not only for the installation of democratic government but for broader democratic consolidation. ${ }^{117}$

\subsection{Elections in the DRC and lessons for Africa}

As pointed out earlier, elections alone do not guarantee the establishment of a true democracy but are essential to it, since no regime would qualify as democratic in our modern era if it does not hold regular elections. To usher in a democracy or contribute to democratic consolidation, elections should meet a number of criteria that need to be revisited.

First, a democratic regime being one based on the rule of law, democratic elections should also be provided for and organised in terms of rules and principles adopted by the legitimate representatives of the people and accepted by the majority of the citizens and parties. These rules and principles cannot be made dependent on the incumbent political leader or party who would decide when elections are to be organised, who should be entitled to vote or stand for elections, under which conditions these elections should be organised, how the electoral process should be managed and which institutions should be involved in the management of the process or in the promulgation of the results. There should be a legitimate constitution and legislation adopted by people's representatives in Parliament to set up the rules and principles which would constitute the 'electoral law'. Arguably, this is the main criterion of democratic elections on which others depend. Without a constitution or electoral legislation adopted or agreed upon by the citizens or the major political parties, elections are unlikely to be open, free and fair.

Second, democratic elections should be fair, open and free. This requires that elections should be held on a regular basis. They should be exempted from any rigging. They should be open to all in the sense that every adult citizen should be entitled to vote although he or she may not actually take part in voting. On the other hand, any citizen or political party should be allowed to participate in these elections. Moreover, they should be allowed to vote or campaign freely. Again, the regularity, fairness, openness and freedom of elections should be provided for by the Constitution and the electoral law.

Third, elections are likely to be open, free and fair when the electoral process is managed by a special body established by law. This body, generally known as an electoral commission, should be impartial. It should be independent from the government of the day, from all political parties and from any other internal or foreign force. Popular participation in the elections and the acceptation of the results of elections are also dependent on the confidence the electoral bodies enjoys among the citizens and major political parties. 
Fourth, the electoral process usually comes to an end with the proclamation of the results. This is left to the judiciary to which the electoral body or commission is subject and which decides the electoral disputes. It is therefore extremely important that both the electoral commission and - even more importantly - the judiciary should be independent and impartial. An electoral process may be totally derailed in the end if the judiciary is biased. Down the line, the judiciary therefore plays a crucial role in determining whether elections were open, free and fair and to be considered democratic.

The recent elections in the DRC took place after decades of authoritarian and single-party rule. It cannot be gainsaid that a major opposition party, namely the Union pour la Démocratie et le Progrès Social (UDPS), called for a boycott and its militants did not take part in the referendum or the electoral process. The Electoral Act was also drafted in such a way as to advantage the incumbent leader, President Joseph Kabila. The electoral commission, which mainly depended on Western powers and the international community that funded the elections, was not really autonomous and independent from these outside actors. Nor was it independent from President Kabila who nominated its chairperson. The number of voters was increased in the provinces that supported the President and his allies. Some vote-rigging took place in a number of constituencies despite the claim by many international observers that the elections were open, free and fair. On the other hand, the judiciary was subjected to the whims of the President because he had the power to appoint and also to remove them from office. In the absence of an independent judicial commission, the members of the judiciary were appointed and could be suspended or dismissed by the President, making it unlikely that they would uphold results which did not declare him the winner of the Presidential elections.

Despite the above pitfalls, the DRC had a Constitution approved by popular referendum and an Electoral Act enacted by a multiparty Parliament - and not just a presidential decree - before going to elections. An Act of Parliament provided for the organisation and functioning of the EIC itself. ${ }^{118}$ The EIC was responsible for the implementation of the Acts of Parliament on referendum, ${ }^{119}$ the identification and registration of voters $^{120}$ and the organisation of elections at all levels. ${ }^{121}$ The EIC managed to overcome much technical, material, financial, administrative and legal obstacles to help the Congolese people enforce their constitutional right to vote in a multiparty environment after decades of undemocratic rule under Mobutu and Laurent-Désiré Kabila. As stressed earlier, however, one should not overlook the main problem it faced and also the major criticism levelled against the EIC. It relates to its independence vis-à-vis both the President Candidate Joseph Kabila and his party on the one hand and,

118 Act No 04/009 of 25 June 2004.

119 Act No 05/010 of 22 June 2004 relating to the organisation of referendum in the DRC.

120 Act No 04/028 of 24 December 2004 relating to the identification and registration of voters in the DRC.

121 Electoral Act (fn 14 above). 
on the other, the international community and even some of its members that largely financed the electoral process. Its opponents held that it was biased in favour of Joseph Kabila, as Father Malu Malu who chaired it was a presidential ally recruited from civil society. The EIC was also perceived as the mouthpiece of the international community that funded the electoral process or of the Comité International d'Accompagnement de la Transition (CIAT), led by Ambassador William Swing and comprising the representatives of the USA, France, Belgium, South Africa, Gabon and Angola.

The EIC did not always act as the independent and impartial institution established by the Constitution and as its denomination suggested. The veil of impartiality of the EIC also fell down when this institution attempted to disqualify Alex Kande and Dominique Kanku as opposition candidates for the positions of governors in the provinces of Kasai Occidental and Kasai Oriental. ${ }^{122}$ Nevertheless, the EIC succeeded in organising competitive elections after decades of undemocratic rule, no matter how critical one could be about the fairness of these elections. Based on the circumstances and the conditions under which it had to operate, the EIC performed better than similar institutions in many other African countries. It even went as far as deciding on a second round of the presidential election despite being chaired by presidential nominees or allies.

The judiciary also had a key role to play as the final arbiter in all constitutional and electoral matters, given the fact that its decisions were binding on all parties pending the creation of a Constitutional Court. ${ }^{123}$ The Supreme Court of Justice confirmed the results of the presidential election as released by the EIC. Presidential candidates such as Azarias Ruberwa (first round) and Jean-Pierre Bemba (second round) contested these results. They complained about irregularities such as the unauthorised vote by procurement or vote by persons not entitled to vote, total absence of witnesses or observers, corruption of EIC officials, and excessive manipulation and intimidation of voters. Although the Court could not change the final results in terms of which Joseph Kabila was proclaimed the winner, these were instances where it could have ordered a new election, a recount or even an invalidation of votes. However, it did not do so. It was only in settling the disputes over the election of the members of the National Assembly that the Supreme Court decided to invalidate the election of some candidates who had been proclaimed as elected by the EIC or to order a new election. ${ }^{124}$

Every year at least one African country goes to the polls. Recent general elections took place in countries such as Benin, Burundi, Central African Republic, Chad, Cameroon, Congo, Ethiopia, Egypt, Kenya, Lesotho, Liberia,

122 On the lists submitted by the MLC and allies in the Union pour la the Nation supporting the opposition leader Jean-Pierre Bemba.

123 DRC Constitution (fn 13 above) arts 149, 157, 160, 161 -169, 172-173, and 223; Electoral Act (fn 14 above)arts $72,74-76,157,172-173$.

124 The Court ordered a new election in some constituencies (Mweka, province of Kasai Occidental, and Befale, province of Equateur) where massive vote rigging occurred. Later on, it reverted to its initial decision and confirmed the results of the election in Mweka. 
Malawi, Mauritania, Mozambique, Namibia, Nigeria, Rwanda, Senegal, Tanzania, Uganda and Zimbabwe. Côte d'Ivoire should be going to elections by the end of the year while South Africa, Zambia and Angola are expected to vote in 2009. There are definitely lessons that the rest of Africa can learn from the DRC 2006 elections, which were among the best multi-party elections ever organised in Africa over the last decades. The fact that the Congolese people went to the polls in a relatively peaceful environment and political leaders ultimately abided by the results was almost a miracle in a country still emerging from war and authoritarianism. Africa should learn from the shortcomings of these elections in order to correct or avoid them. African states can also learn from the success that was achieved to improve when they organise their future elections.

\section{CONCLUSION}

As this article emphasised, democracy cannot be reduced to the holding of elections under a multiparty system. Multiparty elections have been held regularly, with the satisfecit generally delivered by 'international observers' without many African countries entering the promised land of democracy. Although they are not synonymous, elections and multipartyism nevertheless constitute a step forward in the process of establishing genuine democracy.

The DRC held its general elections in 2006 following decades of authoritarian rule. Despite shortcomings in the electoral process, the complexity of the electoral laws and the intricacy of the electoral systems, the elections in the DRC were relatively peaceful and disappointed many prophets of doom. However, as stressed elsewhere, ${ }^{125}$ there are challenges to democratic consolidation in the DRC as well as the rest of the African continent. As scholars such as Sandbrook, ${ }^{126}$ Schatzberg, ${ }^{127}$ Nzongola-Ntalaja and Lee ${ }^{128}$ also observed, some of these challenges relate to external factors ${ }^{129}$ such as the negative role of the international community and globalisation that have contributed to the making of what Mkandawire aptly referred to as "choiceless" democracies. ${ }^{130}$ Others challenges relate to internal or domestic factors like the establishment of the rule of law, the adoption of legitimate constitutions, the enactment of relevant pieces of legislation to guide the process of democratisation and election, the establishment of institutions such as a non-partisan army, police force and security service subject to the rule of law, an autonomous and impartial electoral commission to manage elections, an independent judiciary to preside over the process, the development of a

125 André Mbata B Mangu "Challenges to constitutionalism and democratic consolidation in Africa" (2005) 24 Politeia at 321-330.

126 Sandbrook R "Liberal democracy in Africa” in J E Nyang'oro (ed) Discourses on democracy: Africa in comparative perspective (1996) Dar Es Salaam University Press at 152-153.

127 Schatzberg M “Hijacking change: Zaire 'transition' in comparative perspective” in M Ottaway (ed) Democracy in Africa. The hard road ahead (1997) Boulder: Lynne Rienner 123-125

128 Nzongola-Ntalaja G, Lee M "Introduction" (fn 98 above) 1, 7-8.

129 Idem 322.

130 Mkandawire $\mathrm{T}$ "Crisis management and the making of 'choiceless' democracies" (fn 2 above) at 119-120, 122-130, 133; Joseph R "State, conflict and democracy in Africa," in Joseph (fn 83 above) at $6-7$. 
political and democratic culture among the people, ${ }^{131}$ the existence of vibrant civil society that contributes to empowering the citizenry and a political and an intellectual leadership truly committed to democratic change, ${ }^{132}$ national reconciliation and nation-building. ${ }^{133}$ On the other hand, total economic collapse is incompatible with democracy and failure to improve the economic situation can disappoint the masses that fought for political change as a prerequisite for economic development.

The consolidation of democracy remains extremely difficult, especially at times of economic crisis. ${ }^{134}$ It should therefore go hand in hand with efforts to economic recovery and reconstruction. The eradication of poverty, ${ }^{135}$ wars and rebellions also feature among the challenges that need to be overcome as they pose a great threat to constitutionalism and democracy on the continent. ${ }^{136}$

Suberu pointed out that the challenges to democracy, multiparty, free and fair elections in Africa are enormous but not insurmountable. ${ }^{137}$ Democracy also belongs to Africa and is feasible in Africa. ${ }^{138}$ This reflection on the electoral laws and systems and on the 2006 elections organised in a relatively successful manner in the DRC after decades of authoritarian rule and wars clearly demonstrates that there are lessons that Africa can and should learn from the DRC experience in order to consolidate democracy on the continent.

\section{BIBLIOGRAPHY}

Ake C Democracy and Development in Africa (1996) Washington. Dfic: The Brookings Institution.

Amin S "The Issue of Democracy in Contemporary Third World" in Nyang'oro J E (ed) Discourses on Democracy: Africa in Comparative Perspective (1996) Dar-es-Salaam University Press 64, 70-71.

Act No 04/28 of 24 December 2004 relating to the identification and registration of voters in the Democratic Republic of Congo.

131 See Onalenna D G “Gender and democracy in Botswana: women's struggle for equality and political participation" in Nzongola-Ntalaja \& Lee(fn 83 above) at 39-40; Nwabueze (fn 64 above); Mujaju A B "Civil society at bay in Uganda" in Nzongola-Ntalaja \& Lee (fn 98 above) 42; Nzongola-Ntalaja \& Lee (fn 98 above) at 2.

132 See Huntington (fn 79 above) 316; Wiseman J (fn 65 above) 132, 165, 172-173, 186; Ibrahim J ‘ Political science and the subversion of democracy in Africa' in Nzongola-Ntalaja, Lee M "The state and democracy in Africa" African Association of Political Affairs (1997) 114-117.

133 Ottaway M 'Democracy in Africa. The hard road ahead' Boulder: Rienner (1997) 316.

134 See Van de Walle N "Economic reform and the consolidation of democracy in Africa" in Ottaway(fn 133above); Clapham C \& Wiseman J A "Conclusion: assessing the prospects for the consolidation of democracy in Africa" in Wiseman J "Democracy and Political Change in Sub-Sahara Africa" London \& New York: Routledge (1995) 222.

135 See Van de Walle N "Economic reform and the consolidation of democracy in Africa" in Ottaway (fn 134 above) 15; Clapham C \& Wiseman J A (fn 134 above) 222.

136 See Ibrahim J 137; Hutchful E "Military issues in the transition to democracy" in Hutchful E \& Bathily A The military and militarism in Africa (1998) (eds) Senegal Codesria 599-617; Olukoshi (fn 83 above) 460-464.

137 Suberu RT “Institutions, political culture, and constitutionalism in Nigeria," in D P Franklin \& M J Baun (eds) Political culture and constitutionalism. A comparative approach, Armonk, New York \& London: M E Sharpe (1994) 215

138 See Hinden (fn 80 above), 14; Ilunga Kabongo "Democracy in Africa: Hopes and Prospects," in Ronen (fn 68 above) 35; Ake (fn 70 above) 129-159. 
Act No 05/10 22 June 2004 relating to the organisation of referendum in the Democratic Republic of Congo.

Bangura Y "Authoritarian rule and democracy in Africa: a theoretical discourse" in Nyang'oro J E (ed) Discourses on Democracy: Africa in Comparative Perspective (1996) Dar Es Salaam University Press 64, 70-71.

Bratton M, Posner DN "A first look at second elections in Africa with illustrations from Zambia” in Joseph R State conflict and democracy in Africa Bouwer London: Lynne Rienne Publishers (1996) 378.

Bauer G "Challenges to democratic consolidation in Namibia" in Joseph $\mathrm{R}$ State conflict and democracy in Africa Bouwer London: Lynne Rienne Publishers (1996) 378.

Clapham C and Wiseman I A "Conclusion: assessing the prospects for the consolidation of democracy in Africa" in Wiseman J Democracy and Political Change in Sub-Sahara Africa London \& New York: Routledge (1995) 222.

Conac G "Introduction" in Conac G (ed) L'Afrique en transition vers le pluralisme politique (1993) Paris: Economics 1993.

Constitution de la République Démocratique du Congo, numéro spécial, Journal Officiel de la RDC, 47 ème année, Kinshasa, 18 février 2006; Electoral Act of 9 March 2006; Decision No 003/CEI/BUR/06 of 9 March 2006.

Dahl R Polyarchy: participation and opposition (1971) New Haven Yale University Press.

Dahl R Democracy and its critics (1989) Yale University Press at 220-224

Decision No 003/CEI/BUR/06 of 9 March 2006 relating to the implementation of the Electoral Act.

Electoral Independent Commission Act 04/009 9 June 2004

Electoral Act 06/006 9 March 2006.

Dugard J International Law: A South African Perspective 2nd (2000) Juta Publishers 240-242.

Hinden R "Africa and Democracy" (1963) Encounter Pamphlet no. 8 at 9.

Hoffman J State, Power and Democracy: contentious concepts in practical political theory (1988) Sussex; Wheatsheat Books 31.

Huntington SP The Third Wave: Democratisation in the Late Twentieth Century (1991) University of Okalahoma Press 10.

Hutchful E "Military issues in the transition to democracy in Hutchful E \& Bathily" A (eds) The military and militarism in Africa (1998) Senegal Codesria 599-617.

Glaser D "Discourses of democracy in the South African left: a critical commentary" in Cohen R, Goulbourn Democracy and socialism in Africa (1990) 3 248-251, 270.

Ibrahim J "Political scientists and the subversion of democracy in Africa" in Nzongola-Ntalaja Lee (eds) The state and democracy in Africa: African Association of Political Science Harare (1997) 137. 
Joseph R "State, conflict and democracy in Africa, in Joseph 'State conflict and Democracy in Africa, Boulder \& London: Lynne Rienner Publishers (1999) 6-7.

Mangu A "Conflict in the Democratic Republic of Congo: an international legal perspective" (2003) 28 South African Yearbook of International Law 93-98.

Mangu A "The Conflict in the Democratic Republic of Congo and the protection of rights under the African Charter" (2003) 3 African Human Rights Law Journal (2003) 235, 238-245.

Mangu A "Conflict in the Democratic Republic of Congo: an international legal perspective" (2003) 28 South African Yearbook International Law 237.

Mangu A "From war to peace: the Democratic Republic of Congo in transition” South African Journal of International Affairs (2003) 10159 - 160.

Mangu A Congo, Democratic Republic of the in Gerhard Robbers (ed) Encyclopedia of World Constitutions Vol 1 (2007) 213-214.

Mangu "Challenges to constitutionalism and democratic consolidation in Africa” (2005) 24 Politeia at 321-330.

Mangu A "The road to constitutionalism and democracy in post-colonial Africa" LLD Thesis University of South Africa(2002).

Mkandawire T Introduction in Mbaya Kankwenda (ed) Le Zaïre vers quelles destinées? (1992) IX-X.

Nwabueze BO Constitutionalism in the emergent states (1973) London: Hurst, Enugu: Nwamife Publishers 1.

Nzongola-Ntalaja G "The state and democracy in Africa” in Nzongola-Ntalaja G, Margaret Lee (eds) The state and democracy in Africa (1997) African World Press 15.

Olukoshi A "State, conflict, and democracy in Africa: the complex process of renewal” in Joseph R (ed) State, conflict and democracy in Africa (1999) Boulder Lynne Rienner 457.

Onalenna D G "Gender and democracy in Botswana: women's struggle for equality and political participation" in Nzongola-Ntalaja, Lee M (ed) Africa in perspective, Dar-es-Salaam: Dar-es-Salaam University Press (1996) 31-60.

Ottaway M Democracy in Africa. The hard road ahead Boulder \& London: Lynne Rienner Publishers (1997) 316.

Ronen D "The challenges of democracy in Africa” in Ronen D (ed) Democracy and pluralism in Africa Boulder: Lynne Rienner Publishers (1986) at 1.

Sandbrook R "Liberal Democracy in Africa: A Socialist-Revisionist Perspective” in Nyang'oro J (ed) Discourses on Democracy: Africa in comparative perspective, Dar-es-Salaam: Dar-es-Salaam University Press (1996) 137-138, 143-146.

Schatzberg M “Hijacking change: Zaire 'transition' in comparative perspec- 
tive" in M Ottaway (ed) Democracy in Africa The hard road ahead (1997) Boulder London Lynne Rienner 123-125

Shivji IG Fight My Beloved Continent: New Democracy in Africa (1992) Harare: SAPES Books 2, 44;

Shivju IG "Contradictory Class Perspectives in the Debate on Democracy" in Shivji I G (ed) State and Constitutionalism: An African Debate on Democracy (1991) Harare: SAPES Books 254-255

Sono T "Comments on democracy and its relevance in Africa” African Perspective: Selection of Works(1992).

Suberu RT "Institutions, political culture, and constitutionalism in Nigeria," in Franklin DP, Baun MJ (eds) Political culture and constitutionalism. A comparative approach, Armonk, New York \& London: M E Sharpe (1994) 215.

Sorensen G "Democracy and the developmental state" in Nyang'oro J (ed) Discourses on Democracy: Africa in comparative perspective, Dar-es-Salaam: Dar-es-Salaam University Press (1996).

Wolpe H "The Great Lakes crisis: an American view" (2000) 7 South African Journal of International Affairs 27.

Wiseman JA Democracy in black Africa. Survival and revival New York: Paragon House Publishers (1990) 4.

Van de Walle $\mathrm{N}$ "Economic reform and the consolidation of democracy in Africa” in Ottaway M Democracy in Africa. The hard road ahead Boulder \& London: Lynne Rienner Publishers (1997) 316.

United Nations: Universal Declaration of Human Rights 1948 GA res 217 A (III) of 10 December 1948.

United Nations: International Covenant on Civil and Political Rights 1966 (999 UNTS 171).

Yahmed BB, as quoted by "Pierre-François Gonidec 'Démocratie et développement en Afrique: perspectives internationales et nationales” (1993) 14 Afrique 2000 57-58.

Internet Cites

http://fr.wikipedia.org/wiki/Election_in_the_Democratic_Republic_of_ Congo2006_General_Election accessed on 8 October 2007.

See http://fr.wikipedia.org/wiki/election_presidentielle_congolaise_de_2006 (Deuxième tour) accessed on 8 October 2007.

http://www.un.org/apps/newsFr/storyFAr.asp?News accessed on 8 October 2007.

http://en.wikipedia.org/wiki/ Democratic_Republic_of_the_Congo_general_ election_parliamentary accessed on 8 October 2007.

http://www.digitalcongo.net/article/39312 accessed on 8 October 2007.

http://en.wikipedia.org/wiki/Elections_in_the_Democratic_Republic_of_the_ Congo accessed on 8 October 2007

See http://en.wikipedia.org/wiki/Elections_in_the_Democratic_Republic_of_ the_Congo_gubernatorial_elections accessed on 8 October 2007. 